\title{
Art as an instrument to grasp the difference between the ill and the illness
}

In this article we continue highlighting the importance of art in undergraduate and professional training. We consider necessary to enphasize the power that symbolic language of art has to reflect the ineffable human dimension. ${ }^{1}$

We will discuss how art can contribute to understanding the difference between the pathophysiological process that affects an individual (the ill) and the theoretical construction developed for its interpretational approach (the illness).

In this sense, it is critical to underscore that terms medicine uses to name the different illnesses are arbitrary labels that, although validated by consensus and practical use, are able to segment - in humanly understandable and manageable portions - an enormous and ongoing network of interwoven pathophysiological processes.

Such linguistic gimmick has allowed generations of physicians to consider these problems in terms of illnesses and, based on their conceptualization, try and solve or at least mitigate them. ${ }^{2}$ This explains why certain patients have "atypical" clinical features, such as pneumonia with no fever or a myocardial infarction with no anginal distress. Therefore, confusing a theoretical term (illness) with what actually occurs to the patient (pathophysiology) is like confusing words with objects (Foucault) or, inother words, to mistakenly believe that a map is the territory it attempts to represent. Such confusion implies the risk of not being able to make complex clinical diagnoses.

In art, an enlightening example of this perspective is the painting Las Meninas (The Maids of Honor) by Diego Velázquez. In this masterpiece, Velázquez portrays himself working on a canvas, painting Infanta Margarita surrounded by her entourage (the Maids of Honor) in the court of the Spanish King Philip IV. However, the same scene has been recreated quite differently by other authors: Pablo Picasso (painting), Salvador Dalí (painting), Manolo Valdés (sculpture) and Michel Foucault (philosophical analysis). All of them portrayed a different map of the same reality and were able to do so because reality is a never ending wealth, unlike the narrow confines of its representation. ${ }^{4}$

Such phenomenon also explains why advances made in the knowledge of a certain pathological process or the change in its course related to the treatment in place lead to the coining of new medical terms and classifications. Old labels are now insufficient and require legacy terminology to be expanded and enriched to give rise to a more accurate medical perspective consistent with the current approach to getting cured or ill.

Once again, art provides enlightening examples of this circumstance, such as the work by Pablo Picasso (cubism), Oskar Kokoschka (expressionism), Lewis Caroll (Jabberwocky) and James Joyce (Finnegans Wake). All these authors coined new terms (pictorial and literary, respectively) in order to expand their conceptual frontiers..$^{5-7}$

For instance, James Joyce's Finnegans Wake. Although the novel is basically written in English, Joyce includes in this masterpiece words from at least 70 different languages, in addition to introducing countless portmanteau neologisms, which combine two or more words together to create a new one, to disrupt the linearity of formal thinking and give rise to new concepts.

Examples from the text: ${ }^{8}$

Riverrun = river $($ English $)+$ run (English): a succinct concept of "a river that runs".

Regginbrow = rainbow (English) - reggen (German) + eyebrow (English): a succinct concept of "the rainbow is an eye in the face of rain".

In short, introducing art as an educational tool in medicine helps to achieve a better understanding of the marked differences between two concepts: the ill (reality) and the illness (its representation).

Carlos G. Musso, M.D., and Paula A. Enz, M.D. School of Medicine, Instituto Universitario del Hospital Italiano de Buenos Aires, Argentina

http:/ /dx.doi.org/10.5546/aap.2015.eng.292

\section{REFERENCES}

1. Musso CG, Enz PA. El arte como instrumento educativo en medicina. Arch Argent Pediatr 2014;112(6):494-5.

2. Musso CG. Obras maestras del arte universal y la medicina: Muerta mimosa tuya quieroser Elena Bellamuertede Macedonio Fernandez(1874-1952). Evid Act Pract Ambul. Enprensa 2015. 
3. Musso CG, Enz PA. Semiótica médica. Principios lingüísticos y comunicacionales de uso médico. Buenos Aires: Del hospital ediciones; 2007.

4. Musso CG. Diego Velazquez and his painting: The triadic matter of reality. Humane Medicine Health Care 2007;7(1).

5. Musso CG. We need new terms to better explore emergent clinical settings. [Accessed on: April 1 ${ }^{\text {st }}$, 2015]. Available at: http://www.cardiab.com/content/12/1/156/ comments\#1978698.

6. Musso CG. Obras maestras del arte universal y la medicina: Autorretrato de OskarKokoschka (1886-1980). Evid Act PractAmbul. In press 2015.

7. Musso CG, Enz PA. Arte y naturaleza humana XIII. Rev Hosp Ital BAires 2013; 33(3):109-10.

8. Joyce J. Finnegans wake. New York: Penguin; 1976.

\section{Clinical experience and the value of scientific publications}

Along the course of my professional career, I have heard my colleagues make the most varying comments, ranging from extremely favorable opinions to the most undermining ones, regarding the importance of writing and having scientific articles published. Among the latter, the following are quoted:

1. There are people who do not write papers, but they "work very hard" seeing many patients, and this is what counts.

2. Experience is achieved through work.

3. Writing papers and having them published means very little.

We could propose the following considerations against these arguments:

1. Individuals who write scientific articles and have them published also "work very hard", and they also take time from their family, rest, hobbies and other activities to be able to accomplish all the extra work.

2. It is not true that experience is achieved through work. Working is a necessary requirement, but is not enough. In the case of pediatric clinical practice (as in many other areas), experience does not mean "having seen many patients", but having reflected on those patients that have actually been seen. So, what does this reflection consist of? It requires being able to collect all the information of patients seen, assess its reliability, organize, group, process, analyze and provide a context for such information, ${ }^{1}$ and finally draw a valid conclusion synthesizing the actual "experience".

But in order to do all this, information has to be adequately recorded. Many clinicians may brag about the "large number of sore throats" seen in our professional practices and the "extraordinary experience" it implies. However, the value of this experience fades very quickly once we are asked whether we have carefully recorded the clinical characteristics of all "sore throat cases" seen, whether we have made a systematic survey on their clinical course (for example, at 15 days), and whether we have assessed the degree of compliance with prescriptions, among other things. Without such information, no reflections can be made about those 30 years of having "seen" sore throats.

At medical conferences, we commonly attend presentations on patients with a certain condition and then go back home excited to review our own cases because we know that "at our hospital there are many more patients with that same condition than those presented". However, once we are back at the hospital and review our medical records, we realize that we actually have more of these patients than "them", but we cannot analyze them because one is missing an $\mathrm{x}$-ray, another one is missing a lab test, and yet another one has not attended a consultation in the past four years but no one has called to ask about them, etc. In order to reflect on what we have done, we also need to systematically record our activities. In my opinion, follow-up of chronic patients should observe a specific protocol so that they can be assessed over time. Otherwise, it is very hard to gain "experience", reflect on what has been done based on specific data, and therefore realize whether we are doing things the right way. When such reflection is adequate, even if modest, it deserves to be shared with other colleagues; in the end, this is what a publication is about.

3. Writing an article and have it published means many things. ${ }^{2}$ For example, it means having been able to record information, having sound information available, organizing it and making an effort to draw results. It means having read references, because no one can be so pretentious as to write an article ignoring what others have said on 
the same topic, even though those others are our scientific "competitors". It also means setting up our ideas ${ }^{2-4}$ by means of the written word, which constitutes a skill that requires to be developed. Not every great doctor is capable of writing a good article, these are two different skills. Probing into words is not an easy task, ${ }^{5}$ no one teaches you how to do it, but if we enrich our language, we will enrich our thoughts and our ability to communicate. As any other skill, writing can be learned.

Writing a scientific article also means exposing oneself to peer-review and being willing to accept criticism and change our manuscript. Journals rarely accept an article without making any modifications; most times manuscripts are returned plagued with observations, questions and suggestions. Undergoing such reviews means exposing oneself, and this requires certain scientific maturity and a cultural habit of accepting criticism. Once again, we get exposed when the article is finally published and, at this time, our peers may criticize it again, with greater or lesser virulence. This is the case whenever we write down our thoughts and our own ideas in the article, because there are some authors who fear to state what they think and just copy somebody else's ideas, resulting in brainless science, as brilliantly described by Cereijido. ${ }^{6}$ All this may be dug up from a scientific publication. There may be really good pediatricians who lack the ability to write adequately, but having an article published is an intellectual adventure that I recommend everyone to undertake at least once in their lifetime. If you manage to do it, be sure that you will feel like you have added a new particle to universal knowledge, that you have created something in this world that was not there before. This is a creative task based on "experience", i.e., on our reflections, which is undoubtedly highly valuable by itself and, additionally, we are able to share it with our peers.

Horacio Lejarraga, M.D. Universidad de Buenos Aires Autoridad de Cuenca Matanza Riachuelo (ACUMAR)

http:/ /dx.doi.org/10.5546/aap.2015.eng.293

\section{REFERENCES}

1. Bazerman C. Shapingwritten knowledge. The genre and activity of the experimental article in science. Madison: University of Winsconsin Press; 1988.

2. Lejarraga H. La escritura de un artículo científico. Arch Argent Pediatr 2001;99(3):273-80.

3. Albert T. The A-Z of medical writing. London: BMJ Books; 2000.

4. Day RA. Cómo escribir y publicar trabajos científicos. $2^{\text {da }}$ ed. Washington DC: Organización Panamericana de la Salud; 1996.

5. Borges JL. El idioma de los argentinos. Buenos Aires: Seix Barral; 1994. Capítulo 1, Indagación de la palabra:11-25.

6. Cereijido M. Ciencia sin seso, locura doble. México: SigloVeintiuno; 1994. 